\title{
FACTORS AFFECTING STUDENTS' SATISFACTION ON QUALITY OF TRAINING SERVICES OF STUDENTS STUDYING AT THE INTERNATIONAL SCHOOL - THAI NGUYEN UNIVERSITY
}

\author{
Nguyen Duc Truong', Nguyen Thi Gam², Duong Thi Sen ${ }^{3}$, Ha Trong Quynh ${ }^{1 *}$ \\ ${ }^{I}$ TNU - International School, ${ }^{2}$ TNU - University of Economics and Business Administration \\ ${ }^{3}$ University of Economics and Business, Vietnam National University, Hanoi
}

\begin{tabular}{|c|c|c|}
\hline \multicolumn{2}{|c|}{ ARTICLE INFO } & ABSTRACT \\
\hline Received: & $25 / 6 / 2021$ & The competition among universities in attracting students requires \\
\hline Revised: & $16 / 8 / 2021$ & $\begin{array}{l}\text { university leaders to pay attention to students' voices, survey students' } \\
\text { perceptions of training services provided by the universities to }\end{array}$ \\
\hline Published: & $19 / 8 / 2021$ & understand students' expectation and demand. The research was \\
\hline KEYWORDS & & the International School - Thai Nguyen University and its impact on \\
\hline Influencing factors & & questionnaire survey of 220 students from the first to the fourth year \\
\hline Satisfaction & & selected by stratified random method. Research results indicate that the \\
\hline Students & & level of empathy, facilities, reliability, staff and responsiveness had \\
\hline Training services & & $\begin{array}{l}\text { positive effects on students' satisfaction on the quality of training } \\
\text { services at the International School - Thai Nguyen University. Based on }\end{array}$ \\
\hline Quality of service & & $\begin{array}{l}\text { the research results, a number of recommendations have been proposed } \\
\text { to improve the quality of training services, contributing to enhancing } \\
\text { the quality of training and attracting domestic and foreign learners to } \\
\text { study at the International School - Thai Nguyen University. }\end{array}$ \\
\hline
\end{tabular}

\section{YÊU TỐ ẢNH HƯởNG ĐẾN SỬ HÀ̀ LÒNG CỦA SINH VIÊN VỂ CHẤT LƯỢNG DỊCH VỤ ĐÀO TẠO CỦA SINH VIÊN KHOA QUỐC TẾ - ĐẠI HỌC THÁI NGUYÊN}

\author{
Nguyễn Đức Trường ${ }^{1}$, Nguyễn Thị Gấm ${ }^{2}$, Dương Thị $\operatorname{Sen}^{3}$, Hà Trọng Quỳnh ${ }^{1 *}$ \\ ${ }^{1}$ Khoa Quốc tế - ĐH Thái Nguyên, ${ }^{2}$ Truờng Đại học Kinh tế và Quản trị kinh doanh-ĐH Thái Nguyên \\ ${ }^{3}$ Truờng Đại học Kinh tế - ĐH Quốc gia Hà Nội
}

\begin{tabular}{|c|c|c|}
\hline \multicolumn{2}{|c|}{ THÔNG TIN BÀI BÁO } & TÓM TẮT \\
\hline Ngày nhận bài: & $25 / 6 / 2021$ & Sự cạnh tranh giữa các trường đại học với nhau trong việc thu hút sinh \\
\hline Ngày hoàn thiện: & $16 / 8 / 2021$ & $\begin{array}{l}\text { viên đòi hỏi ban lãnh đạo các trường đại học cần lắng nghe tiếng nói của } \\
\text { sinh viên, khảo sát sự cảm nhận của sinh viên về dịch vụ đào tạo nhà }\end{array}$ \\
\hline Ngày đăng: & $19 / 8 / 2021$ & $\begin{array}{l}\text { trường đang cung cấp để biết sinh viên muốn gì và cần gì. Nghiên cứu } \\
\text { được thưc hiên nhằm đánh giá thưc trang chất lương dich vu đào tao tai }\end{array}$ \\
\hline \multicolumn{2}{|l|}{ TÙ’ KHÓA } & Khoa Quốc tế - Đại học Thái Nguyên và ảnh hưởng của nó tới sự hài lòng \\
\hline \multicolumn{2}{|l|}{ Yếu tố ảnh hưởng } & hỏi 220 sinh viên từ năm thứ nhất đến năm thứ tư được lựa chọn theo \\
\hline \multicolumn{2}{|l|}{ Sự hài lòng } & phương pháp ngẫu nhiên phân tích. Kết quả nghiên cứu cho thấy mức độ \\
\hline \multicolumn{2}{|l|}{ Sinh viên } & ông, cơ sở vật chất, độ tin cậy, nhân viên và mức độ đáp ứng có ảnh \\
\hline \multicolumn{2}{|l|}{ Dịch vụ đào tạo } & $\begin{array}{l}\text { tich cực den sự hal long cua sinn vien den chat lượng dịch vụ dao } \\
\text { Khoa Ouốc tế - Đai hoc Thái Nguvên. Dưa vào kết quả nghiên cứu. }\end{array}$ \\
\hline \multicolumn{2}{|l|}{ Chất lượng dịch vụ } & $\begin{array}{l}\text { một số kiến nghị đã được đề xuất nhằm nâng cao chất lượng dịch vụ đào } \\
\text { tạo gòp phần nâng cao chất lượng đào tạo và thu hút người học trong và } \\
\text { ngoài nước tới học tập tại Khoa Quốc tế - Đại học Thái Nguyên. }\end{array}$ \\
\hline
\end{tabular}

DOI: $\underline{\text { https://doi.org/10.34238/tnu-jst.4696 }}$

\footnotetext{
* Corresponding author. Email: quynhht@tnu.edu.vn
} 


\section{Introduction}

International integration has created favorable conditions for Vietnam to develop socioeconomy, exchange and acquire new knowledge and transfer science and technology, and share experiences with each other. In line with the trend, the university system is inevitable to do the internationalization, which is both an opportunity and a challenge and pressure for institutes and universities in our country to improve the quality of education. Over the past years, universities in Vietnam have also increasingly focused on building and completing management, planning, design, teaching and research in order to further improve the quality of training in order to achieve higher education standards which can best meet the needs of human resources not only in the country but also abroad.

During university-level human resource training, students are the direct object of the training process and are also the main "products", so students' feedbacks on satisfaction with training quality play an important role. This is an essential and objective information channel which makes a great contribution to the assessment of the current training quality, helps schools to make reasonable adjustments towards better meeting the needs of learners and society.

According to Kotler and Keller [1], satisfaction is a state of a person's level of feeling derived from comparing the perception of a product with the person's expectations. Oliver [2] and Zineldin [3] also stated that customer satisfaction is the emotional feedback of customers to a service provider on the basis of comparing the difference between what they receive and what they previously expected. According to Douglas et al. [4], important aspects of training services relate to core services such as lectures, knowledge acquisition, class notes and classroom and equipment arrangement, lecturers' good professional qualifications. Chen et al. [5] pointed out that the factors from the satisfaction model which can explain a large number of variables on student loyalty include management of the school, academic performance, interpersonal relationships, and facilities.

Nguyen Thanh Long [6] did a research on using SERVPERF scale to assess the quality of higher education at An Giang University. The results of multivariate regression analysis showed that student satisfaction depended on the factors of lecturers, facilities, trust and sympathy. Nguyen Khai Hoan and Nguyen Phuong Thao [7] studied the relationship between the quality of training service and the satisfaction of students at Tan Trao University. Accordingly, among five factors of dependability, application potential, service capacity, sympathy, and facilities, sympathy and service capacity had the most influence on student satisfaction.

The International School of Thai Nguyen University was established by Decision No. 467/QD-DHTN dated June 16th, 2011 of the Director of Thai Nguyen University. The International School is responsible for university education with 4 majors including International Business, Business Administration, Accounting, Environmental Management \& Sustainability. The training program at the International School is an advanced program imported from the UK. Every year, the International School has nearly 200 domestic and foreign students enrolled in the school.

Finding out students' satisfaction with the products provided by the International School Thai Nguyen University is very important. On that basis, the International School - Thai Nguyen University will provide students with better services which are suitable for learners' requirements, bringing them the possible highest satisfaction, at the same time enhancing the position and promote its brand to everyone, especially to parents and high school students in their selecting the future school.

The research was conducted with the aim of assessing the satisfaction of students about the training services of the International School, Thai Nguyen University and proposing solutions to improve the training quality of the International School, contributing to attract enrollment and affirm position of the International School in providing high-quality human resources. 


\section{Methodology research}

\subsection{Research models}

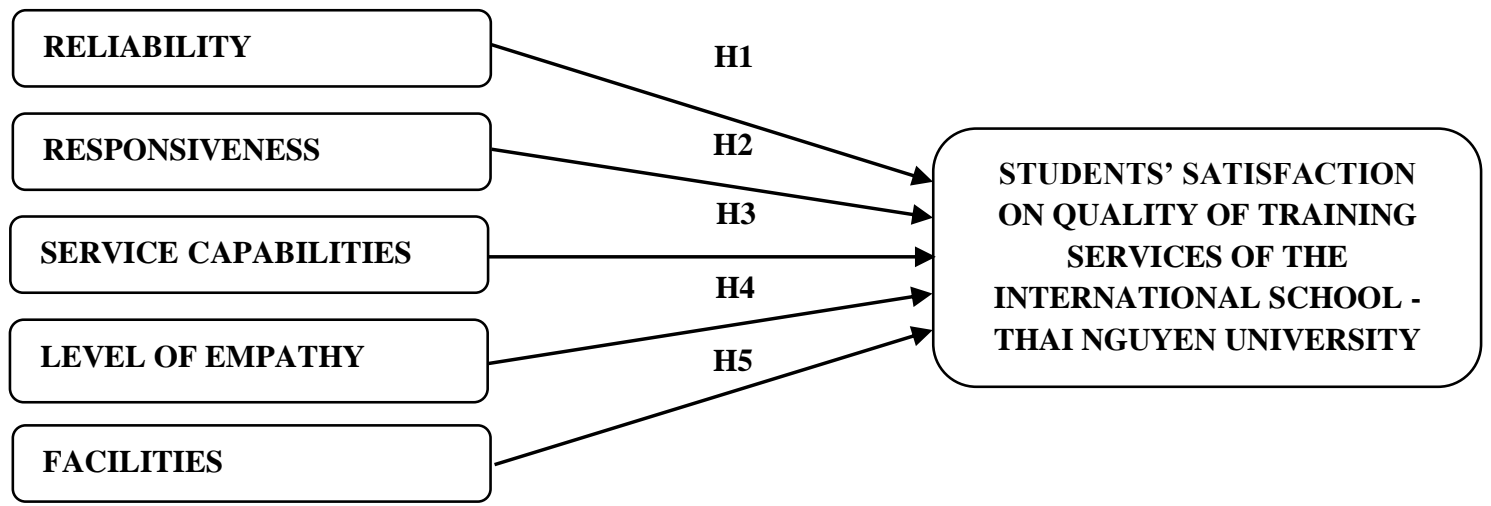

Figure 1. Research models

From the research of [1] - [7], a research model (Figure 1) was proposed to measure student's satisfaction about the quality of training services at the International School - Thai Nguyen University through relationship between service quality's components and customer satisfaction.

\subsection{Methods of collecting information}

* Subjects of the survey: Subjects of the survey are students studying in all majors and courses of the International School, Thai Nguyen University.

* Sample size: The sample size was calculated using the following formula [8].

$$
\mathrm{n}=\frac{\mathrm{NZ}^{2} p(1-p)}{N d^{2}+Z^{2} p(1-p)}
$$

where:

$\mathrm{n}=$ Desired sample size

$\mathrm{Z}=$ Standard deviation, at 1.96 , corresponding to a $95 \%$ confidence level

$\mathrm{p}=$ Overall targets were assessed to have specific general characteristics, usually at $50 \%(0.5)$.

$\mathrm{d}=$ Expected accuracy, usually at 0.05

The number of students studying at the International School as of the time of implementation was 471 students, so the number of samples to choose was:

$$
\mathrm{n}=\frac{471 \times 1.96^{2} \times 0.5 \times(1-0.5)}{471 \times 0.05^{2}+1.96^{2} \times 0.5 \times(1-0.5)}=211.58
$$

So the minimum number of samples to get was 212 questionnaires. To ensure the minimum number of samples, the author investigated 220 questionnaires. The selected samples ensure the representativeness of the group of respondents, both representative and broadly investigated.

Sampling method: Based on the student list of the International School, students were divided into groups based on the criteria of majors and courses. Based on the list of students divided into groups of respondents, the rate of sample selection from the target groups was calculated. After that, the selection of research samples from groups of subjects investigated was conducted by random methods to ensure both the correct rate calculated and the correct number of survey samples. Based on the number of students of each course and each major, the number of questionnaires was allocated as presented in table 1 . 
Table 1. Investigation sample selection

\begin{tabular}{|c|c|c|c|c|c|}
\hline \multirow[b]{2}{*}{ No. } & \multirow[b]{2}{*}{ Criteria } & \multirow[b]{2}{*}{$\begin{array}{l}\text { Number of students } \\
\text { currently enrolled }\end{array}$} & \multicolumn{3}{|c|}{ Number of samples } \\
\hline & & & Total & $\begin{array}{l}\text { Business } \\
\text { Major }\end{array}$ & $\begin{array}{c}\text { Environment } \\
\text { major }\end{array}$ \\
\hline 1 & Freshmen/ First-year students & 161 & 75 & - & - \\
\hline 2 & Sophomore/ Second-year students & 133 & 62 & 58 & 4 \\
\hline 3 & Junior/ Third-year students & 101 & 48 & 45 & 3 \\
\hline \multirow[t]{2}{*}{4} & Senior/ Fourth-year students & 76 & 35 & 33 & 3 \\
\hline & Total & 471 & 220 & 136 & 10 \\
\hline
\end{tabular}

After conducting the survey, the author obtained 220 survey questionnaires, including 03 invalid survey questionnaires. Thus, the number of survey questionnaires used for analysis was 217 survey questionnaires.

* Form of survey: the survey was conducted through direct interviews with the respondents by using a questionnaire.

* Time of survey: in May, 2020

* Scale of the questionnaire: The questionnaire was built by the author based on the evaluation of two factors "Importance" and "score". The 5-level Likert Scale was used in this research. The scale was calculated as follows: 1 - Very Dissatisfied, 2 - Dissatisfied, 3 Moderate/Yes or No, 4- Satisfied and 5- Very Satisfied.

\section{Research findings}

\subsection{Test of the scale by Cronbach's alpha coefficient}

* Test of the scale of training service quality

The training service quality scale was measured through 5 components: reliability (REL); response (RES); empathy (EMP); service capacity (ASS) and facilities (TAN). After performing the test, the author obtained the following results:

The value of the coefficients of each factor was greater than 0.7 ; the variable and total correlation coefficient was greater than 0.3 (except for TAN4 and TAN6 with variable and total correlation coefficient less than 0.3 ). TAN4 had Corrected Item-Total Correlation $=0.257$. TAN6 had Corrected Item-Total Correlation $=0.180$. Therefore, the variables TAN4 and TAN6 were removed from the alpha test.

After removing TAN4, TAN6 from the test and re-testing, the Alpha coefficient of the tangible factor increased from 0.729 to 0.778 .

* Test of scale of student's satisfaction

When performing the test of scale of student's satisfaction using Cronbach's alpha coefficient, the author obtained the following test results: the correlation coefficient between the variable and the total was greater than 0.3 and the Alpha was greater than 0.7. Thus, all the items of the student's satisfaction scale satisfied the conditions and were included in the analysis in the next steps.

\subsection{The analysis of discovery factor EFA}

First time: Put all 32 research variables into factor analysis, the results of the first analysis were as follows: $\mathrm{KMO}=0.895$; Eigenvalua $(1.082)>1$, the total extraction $(59.594 \%)>50 \%$ and there was 1 variable with the load factor < 0.5 (TAN7: The wifi system is strong enough to access and find the necessary information).

The second time: After removing the variable TAN7, the author continued to take one variable out of the EFA factor analysis with the results of the second analysis as follows: $\mathrm{KMO}=$ 0.895; Eigenvalua $(1.082)>1$, the total variance extracted $(60.395 \%)>50 \%$ and there were 3 
variables with load factor <0.5 (REL7: Reliable, fair and convincing assessment of learning results; TAN5: The International School's support services such as parking lot, sports, etc are very good; EMP1: The theoretical and practical lessons are conveniently arranged for students).

The third time: After eliminating 3 unsuitable variables, the remaining 28 variables continued to be included in EFA factor analysis with Varimax rotation, factor results were extracted according to Principal Component Analysis method.

After factor analysis, there was a component of the previous training service quality scale, "service capabilities", was excluded from the research model. Instead, there were two new components: "lecturers" and "staff". This was completely reasonable in terms of content. Concretely, based on the actual case at the International School, the two main subjects of the "service capabilities" component were lecturers and staff that were evaluated differently by students. All elements of the new scale would be used to replace the previous scale in the subsequent analysis.

\subsection{Research models adjustment and hypotheses}

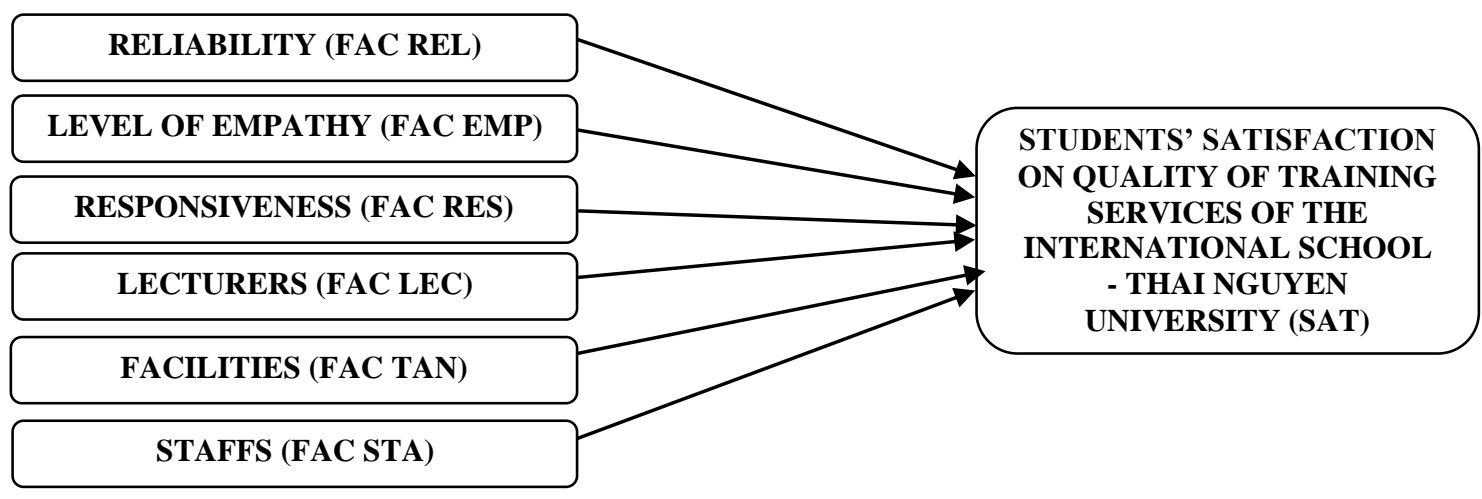

Figure 2. Model of satisfaction assessment of students enrolled in the International School about training service quality (after adjustment)

After conducting the test and analysis above, the results showed that the proposed research model was no longer suitable for the specific case of measuring satisfaction of students enrolled in the International School. The new training service quality scale was measured from a component consisting of 28 observed variables, which were "Reliability level" - FAC_REL; "Empathy level" - FAC_EMP; "Responsiveness" - FAC_RES; "Lecturers" - FAC_LEC; "Facilities" - FAC_ TAN; and "Staffs" -FAC_STA. The research model and hypotheses were adjusted as presented in Figure 2.

\subsection{Regression analysis and model testing}

\subsubsection{Describe the factors that measure satisfaction level}

After factor analysis and recalculation of the new factors, the results were displayed in Table 2. Accordingly, REL - reliability, RES - responsiveness, LEC - lecturer had the average value larger the EMP factor - empathy level, TAN - facilities, STA - staffs are close to equal. This proved that the students' assessment of these factors was relatively good. The largest average value was 3.995 for the factor "lecturers" and the smallest factor was 3.432 for the factor "facilities". TAN - facilities had the smallest mean, proving that the majority of students were not satisfied with the factors of the International School's facilities when surveying.

In general, as it can be seen, the students of the International School relatively agreed with the factors of service quality except for 2 factors: "facilities" and "staffs". However, in order to know among factors REL, RES, LEC, EMP, TAN and STA, which factors have a significant influence, 
which factors have a small effect on students' satisfaction, we need to conduct the correlation analysis step and the next regression.

Table 2. Descriptive statistics of the factors

\begin{tabular}{lccccc}
\hline & N & Minimum & Maximum & Mean & Std. Deviation \\
\hline RELIABILITY & 217 & 1.00 & 5.00 & 3.629 & 0.65498 \\
LEVEL OF EMPATHY & 217 & 1.00 & 5.00 & 3.471 & 0.67706 \\
RESPONSIVENESS & 217 & 1.00 & 5.00 & 3.701 & 0.65028 \\
LECTURERS & 217 & 1.00 & 5.00 & 3.995 & 0.57889 \\
FACILITIES & 217 & 1.00 & 5.00 & 3.432 & 0.88596 \\
STAFFS & 217 & 1.00 & 5.00 & 3.495 & 0.80287 \\
Valid N (listwise) & 217 & & & & \\
\hline
\end{tabular}

\subsubsection{Pearson correlation analysis}

The correlation between the dependent variable (Students' satisfaction) and the independent variable (trust, empathy, responsiveness, lecturers, facilities, and staffs) had coefficients of greater than 0.1 ; the highest was the empathy level $=0.620$ and the lowest was the lecturers $=$ 0.434. Thus, we can conclude that the independent variable can be included in the model to explain the dependent variable. On the other hand, besides the correlation between the independent variables and the dependent variables, there was also correlation between the independent variables of the scale of training services quality, the correlation coefficients among the variables were larger than 0.1 . Concretely, the lowest correlation coefficient was 0.279 , the highest correlation coefficient was 0.465 . Therefore, all these variables were considered independent variables in the next regression models. Because of the correlation of these variables, attention should be paid to the problem of multicollinearity in subsequent analysis.

\subsubsection{Multivariate regression analysis}

Through the results of Pearson correlation analysis above, we can see that all independent variables of the model were strongly correlated with the dependent variable; therefore, all these variables were selected for inclusion in the next analysis step, which is multivariate regression analysis.

In this analysis, to evaluate the suitability of the model, we used the determination coefficient $\mathrm{R} 2$ or adjusted R2. These two values represent the suitability of the model, and the value of R2 or adjusted R2 must be greater than or equal to 0.5 .

On the other hand, to test the suitability of the model, F-test was used; this test hypothesizes $\mathrm{H} 0=$ independent variables that do not affect the dependent variables. If the sig value is very small, < 0.05 , it is safe to reject the hypothesis $\mathrm{H} 0$ and this means that the multiple linear regression model is suitable for the data set.

With the Enter method (the variables included once), the results of the multiple linear regression analysis are given below.

Table 3. The regression results using the method Enter

\begin{tabular}{ccccc}
\hline Model & R & R Square & Adjusted R Square & Std. Error of the Estimate \\
\hline 1 & $0.781^{\text {a }}$ & 0.610 & 0.606 & 0.45861 \\
\hline a. Predictors: (Constant), STA, REL, TAN, LEC, RES, EMP &
\end{tabular}

Table 3 shows that the value $\mathrm{R} 2=0.610$ and adjusted $\mathrm{R} 2=0.606$. This proves that the model achieved the adequacy level of $1 \%$; or in other words, $60.4 \%$ of the variability of the students' satisfaction variable (SAT) was explained by the independent variable in the model. 
Table 4. The analysis results of variance ANOVA

\begin{tabular}{|c|c|c|c|c|c|c|}
\hline & \multicolumn{6}{|c|}{$A N O V A^{b}$} \\
\hline & Model & Sum of Squares & df & Mean Square & $\mathbf{F}$ & Sig. \\
\hline \multirow[t]{3}{*}{1} & Regression & 73.852 & 4 & 23.309 & 110.821 & $0.000^{\mathrm{a}}$ \\
\hline & Residual & 44.599 & 213 & 0.210 & & \\
\hline & Total & 118.451 & 217 & & & \\
\hline
\end{tabular}

The results in Table 4 show that the F-statistic had very small sig value which was equal to 0.000 , so the regression model built was suitable for the data collected. Thus, the independent variables in the model had relationships with the dependent variable.

Through the above results, the model was seen not to violate the multi-collinearity phenomenon because the variance magnification coefficients of independent variables (VIF) were all less than 2 , so the chain correlation phenomenon (multicollinearity problem) was not necessary to be considered.

The result also shows sig. values of the independent variables REL, EMP, RES, TAN, STA were less than 0.05 , so these independent variables had impacts on students' satisfaction with 95\% reliability. However, in the independent variable included in the initial multiple linear regression analysis, there was a variable LEC with sig value. $=0.108>0.05$, the alternative hypothesis that lecturers have impacts on students' satisfaction was rejected. At the same time, we can also see that with a reliability of $95 \%$, the independent variable LEC - lecturers had no effects on satisfaction of students enrolled in the International School. In terms of content value, it is possible that lecturers of the International School ensured the training quality factors, so students did not pay much attention to this factor. In other words, according to the Kano model, this factor belongs to the group of basic characteristics, must have, so whether to increase or decrease this factor will have small effect on students' satisfaction. However, lecturers' activities such as being on time for class, taking care of students... were factors that made students satisfied.

Table 5. Table of analysis of multivariate regression coefficients

\begin{tabular}{|c|c|c|c|c|c|c|c|c|}
\hline & \multirow[t]{2}{*}{ Model } & \multicolumn{2}{|c|}{$\begin{array}{l}\text { Unstandardized } \\
\text { Coefficients }\end{array}$} & $\begin{array}{c}\text { Standardized } \\
\text { Coefficients } \\
\end{array}$ & \multirow[t]{2}{*}{$\mathbf{t}$} & \multirow{2}{*}{ Sig. } & \multicolumn{2}{|c|}{$\begin{array}{c}\text { Collinearity } \\
\text { Statistics }\end{array}$} \\
\hline & & B & Std. Error & Beta & & & Tolerance & VIF \\
\hline \multirow[t]{7}{*}{1} & (Constant) & -0.489 & 0.156 & & -3.127 & 0.002 & & \\
\hline & REL & 0.284 & 0.038 & 0.254 & 7.210 & 0.000 & 0.728 & 1.374 \\
\hline & EMP & 0.281 & 0.042 & 0.262 & 6.711 & 0.000 & 0.605 & 1.654 \\
\hline & RES & 0.092 & 0.043 & 0.083 & 2.186 & 0.028 & 0.620 & 1.613 \\
\hline & LEC & 0.072 & 0.045 & 0.057 & 1.609 & 0.108 & 0.727 & 1.376 \\
\hline & TAN & 0.214 & 0.029 & 0.260 & 7.425 & 0.000 & 0.744 & 1.345 \\
\hline & STA & 0.155 & 0.032 & 0.172 & 4.618 & 0.000 & 0.677 & 1.477 \\
\hline
\end{tabular}

a. Dependent Variable: SAT

On the other hand, we see that the standardized regression coefficients (Beta) of the independent variables were all positive signs, which means that these variables were positively related to the dependent variable of students' satisfaction. From the results in Table 5, we formed a multivariate regression equation with standardized Beta coefficients as follows:

$$
\mathrm{SAT}=0.254 \mathrm{REL}+0.262 \mathrm{EMP}+0.083 \mathrm{RES}+0.260 \mathrm{TAN}+0.172 \mathrm{STA}
$$




\subsubsection{Test the hypotheses of the research model}

We see that there is a hypothesis that needs to be tested as $\mathrm{H} 1$ to H6, both of which provide a positive relationship between the scale of training service quality and the satisfaction of students enrolled in the International School. Through the analysis results above, based on sig. value in the multivariate regression analysis, the author has found that with reliability of 95\%, 5 initial hypotheses namely $\mathrm{H} 1, \mathrm{H} 2, \mathrm{H} 3, \mathrm{H} 5, \mathrm{H} 6$ were accepted; the hypothesis $\mathrm{H} 4$ was rejected.

The model in Figure 3 clearly shows the influence of these factors on the satisfaction of students of the International School including reliability"; "level of empathy"; "responsiveness"; "facilities" and "staffs", among which the most influential factors were "facilities" and "level of empathy"; followed by "reliability"; "staffs" and finally "responsiveness".

After regression analysis, there were 5 factors that affected students' satisfaction: facilities, empathy level, reliability, responsiveness and staffs. Based on standardized Beta coefficients, the importance of these factors to students' satisfaction was determined. On the other hand, descriptive statistics also gave us the results of the students' assessment towards these 5 factors.

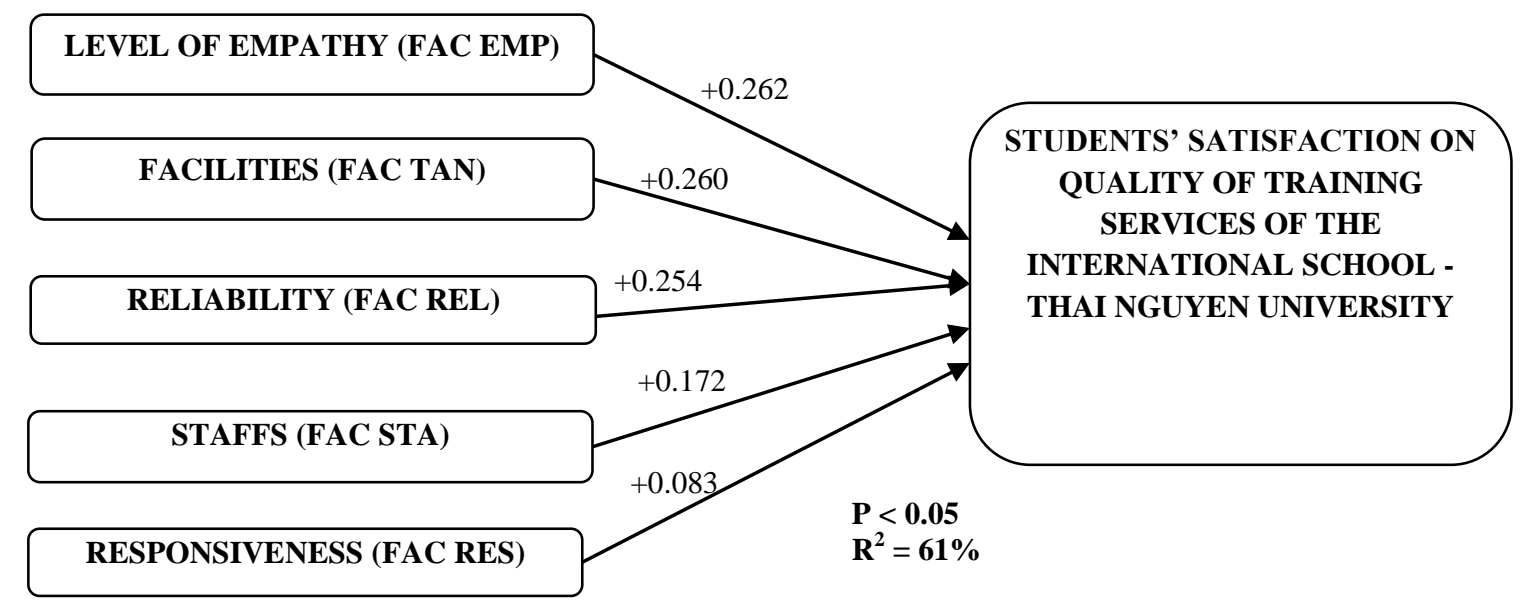

Figure 3. The influence level of these factors on students' satisfaction

Table 6. Standardized weights and average values of all factors

\begin{tabular}{ccc}
\hline Factors & Standardized weights & Average values \\
\hline FAC_TAN & 0.260 & 3.432 \\
FAC_EMP & 0.262 & 3.471 \\
FAC_REL & 0.254 & 3.629 \\
FAC_STA & 0.172 & 3.495 \\
FAC_RES & 0.083 & 3.701 \\
\hline
\end{tabular}

Table 6 reveals that the factors "facilities" and "level of empathy" had the highest weight, proving that these two factors had the most significant effects on students' satisfaction. Simultaneously, these two factors also had the lowest average value of the 5 factors. This shows that although these were two important factors, students were most dissatisfied and underestimated. Therefore, these two factors should be prioritized to improve immediately.

The factor "staffs" whose weight was small was underestimated at an average level, so this factor should be prioritized to improve after two factors "facilities" and "level of empathy". The other two factors "reliability" and "responsiveness" also affected students' satisfaction and were rated as good by students but with low GPA, so these are also problems that need improving. 


\section{Conclusions and recommendations}

\subsection{Conclusions}

Research results show that, after testing, supplementing and adjusting, the scales achieved the reliability and allowable value. The results also show that the quality of training services after factor analysis of EFA including reliability, responsiveness, empathy level, facilities, lecturers and staffs were different from the prototype SERVPERF scale because the factor of service capabilities was separated into 2 components: lecturers and staffs. The results of multivariate regression analysis also show the relationship between students' satisfaction and 5 factors including facilities, reliability, empathy, responsiveness and staffs. This result is similar to the research of Nguyen Thi Hong Van [9].

The factor "level of empathy" had the highest weight with peta coefficient of 0.262 . It proves that this factor had the most impact on student satisfaction. This result is similar to the research of Khai Hoan Nguyen and Phuong Thao Nguyen [7]. The questions of this factor focused on whether the lecturer and staff of International School really share, sympathize and understand students. The second factor that had a great influence on student's satisfaction was "facilities". This result is similar to the research of Pham Thi Lien [10]. This factor was formed from the synthesis of 7 variables of the scale "facilities". All questions focused on equipment, classrooms, libraries, internet, living services... for the learning process of students at the International School. "Reliability" and "staff" also had a significant influence on student's satisfaction. The factor "responsiveness" had the least influence on student's satisfaction with $\beta=0.082$. This result is similar to the research of Nguyen Thi Hong Van [9].

\subsection{Recommendations}

Through the results of analysis and calculation, the authors recommend some solutions that need to be implemented as follows:

- In addition to the expansion of investment and construction of facilities, it is necessary to refocus on the quality of the facilities at the old facilities, to ensure that students are satisfied with the quality of training services provided by the International School.

- It is necessary to periodically consult, understand practical needs of students and build a good relationship with students.

- The School should arrange, reorganize the management apparatus and adjust more appropriately to improve the quality of student service.

- The School should organize training and fostering professional capacity for staffs to improve service capacity.

- It is also important to improve the quality of lecturers by creating favorable conditions for lecturers to have the opportunity to study and do professional research at home and abroad.

- The service quality assessment scale and student's satisfaction need improving on a regular basis.

- It is necessary to build a quality assurance system in the International School.

- The School should further diversify types of training such as continuity training, joint training in Vietnam and abroad to effectively exploit the existing facilities while changing and further promoting the school's brand throughout the provinces in the country and neighboring countries.

\section{REFERENCES}

[1] P. Kotler and K. Keller, Marketing Management, 12th ed. Prentice Hall, Upper Saddle River, 2006.

[2] R. L. Oliver, "Whence Consumer Loyalty," Journal of Marketing, vol. 63, pp.33-34, 1999. 
[3] M. Zineldin, "Beyond relationship marketing: technologicalship marketing," Marketing Intelligence \& Planning, vol. 18, no. 1, pp. 9-23, 2000.

[4] J. Douglas and A. Douglas, "Measuring student satisfaction at a UK university," Quality Assurance in Education, vol. 14, no. 3, pp. 251-267, 2006.

[5] Y.-F. Chen, C.-H. Hsiao, and W.-C. Lee, "How does student satisfaction influence student loyaltyFrom the relationship marketing perspective," preseted in The Seventh National Educational Conference, Taiwan, 2005.

[6] T. L. Nguyen, "Using the SERVPERF scale to assess the quality of higher education," Scientific reports, An Giang University, 2006.

[7] K. H. Nguyen and P. T. Nguyen, "Research on the relationship between training service quality and student satisfaction at Tan Trao University," Tan Trao University Journal of Science, vol. 3 no. 6, pp. 59-63, 2017.

[8] F. P. David, Understanding and doing Research: a handbook for beginners. Panorama Printing Inc, 2005.

[9] H. V. Nguyen, "Assessing of student's satisfaction on training service quality at Hung Vuong University, Ho Chi Minh City," Graduate Thesis, Hung Vuong University, Ho Chi Minh City, 2013.

[10] T. L. Pham, "Training service quality and student's satisfaction: A case study of the College of Economics, Vietnam National University, Ha Noi," VNU Joural of Science: Economics and Business, vol. 32, no. 4, pp. 81-89, 2016. 